\title{
The Fiduciary Obligations of Financial Advisors Under the Law of Agency
}

\section{Citation}

Robert H. Sitkoff, The Fiduciary Obligations of Financial Advisors Under the Law of Agency, $27 \mathrm{~J}$. Fin. Plan. 42 (2014).

\section{Permanent link}

http://nrs.harvard.edu/urn-3:HUL.InstRepos:14976370

\section{Terms of Use}

This article was downloaded from Harvard University's DASH repository, and is made available under the terms and conditions applicable to Other Posted Material, as set forth at http:// nrs.harvard.edu/urn-3:HUL.InstRepos:dash.current.terms-of-use\#LAA

\section{Share Your Story}

The Harvard community has made this article openly available.

Please share how this access benefits you. Submit a story.

\section{Accessibility}




\section{HARVARD}

JOHN M. OLIN CENTER FOR LAW, ECONOMICS, AND BUSINESS

\section{THE FIDUCIARY OBLIGATIONS OF FINANCIAL ADVISORS UNDER THE LAW OF AGENCY}

Robert H. Sitkoff

Published in the Journal of Financial Planning, Vol. 27, No. 2 (2014)

Discussion Paper No. 770

$06 / 2014$

Harvard Law School

Cambridge, MA 02138

This paper can be downloaded without charge from:

The Harvard John M. Olin Discussion Paper Series: http://www.law.harvard.edu/programs/olin_center/

The Social Science Research Network Electronic Paper Collection: http://ssrn.com/abstract=2234830 


\title{
The Fiduciary Obligations of Financial Advisers under the Law of Agency
}

\author{
by Robert H. Sitkoff
}

Robert H. Sitkoff is the John L. Gray Professor of Law at Harvard University. He is an expert on fiduciary law and practice, including fiduciary investment, trust law, and probate law. He has published widely in scholarly journals and has served as a consultant and expert witness in fiduciary litigation. (rsitkoff@law.harvard.edu).

Note: This paper, which was sponsored by Federated Investors Inc., draws on Robert H. Sitkoff, The Economic Structure of Fiduciary Law, 91 B.U.L. Rev. 1039 (2011). In accordance with Harvard Law School's policy on faculty conflicts of interest, Professor Sitkoff discloses certain outside activities, one or more of which may relate to the subject matter of this article, at law.harvard.edu/ faculty/COI/2013_Sitkoff_Robert.html.

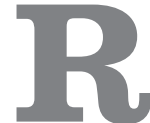
egardless of whether a financial adviser qualifies as an "investment adviser" under the federal securities laws, and so is a fiduciary under federal law, the adviser may be an agent of the client under the common law of agency. In such situations, as a matter of state agency law the adviser is a fiduciary who will be subject to liability for any breach of his fiduciary duties to the client. Because state agency fiduciary law is not coterminous with federal law, and because it can pertain to a financial adviser who is not a fiduciary under federal law, a financial adviser who ignores the possibility of

\section{Executive Summary}

- Regardless of whether a financial adviser qualifies as an "investment adviser" under federal securities laws, and so is a fiduciary under federal law, the adviser may be an agent of the client under the common law of agency, making the adviser a fiduciary as a matter of state common law.

- The common law of agency imposes fiduciary duties of loyalty, care, and a host of subsidiary rules that reinforce and give meaning to loyalty and care as applied to specific circumstances.
- This paper considers how the fiduciary duties of state agency law might be applied to a financial adviser with discretionary trading authority over a client's account.

- This paper surveys the governance problem to which the fiduciary obligation is directed, examines the legal context by considering how fiduciary obligation mitigates this problem, and examines several potential applications of agency fiduciary law to financial advisers, including principal trades. fiduciary status under state agency law acts at his peril.

The common law of agency imposes fiduciary duties of loyalty, care, and a host of subsidiary rules that reinforce and give meaning to loyalty and care as applied to specific circumstances. In the event of an agent's breach of fiduciary duty, the principal is entitled to an election among remedies that include: (1) compensatory damages to offset losses incurred or to make up gains forgone owing to the breach; (2) disgorgement by the agent of any profit accruing from the breach or compensation paid by the principal; or

(3) punitive damages.

This paper considers how agency fiduciary law might be applied to a financial adviser with discretionary trading authority over a client's account. The paper assumes that the adviser is an agent of the client under the common law of agency. Putting that question to the side, ${ }^{1}$ this paper focuses instead on the fiduciary consequences of such status. ${ }^{2}$ Part I provides economic context by surveying the underlying governance issue, known in the literature as an agency problem, to which the fiduciary obligation is directed. Part II examines the legal context by considering how fiduciary obligation mitigates this problem. Part III examines several potential applications of agency 
fiduciary law to a financial adviser, including principal trades and the role of informed consent by the client. A short conclusion follows.

\section{Part I: The Agency Problem}

The law tends to impose fiduciary obligation in circumstances that present what economists call a principal-agent or agency problem. ${ }^{3}$ An agency problem arises whenever one person, the principal, engages another person, the agent, to undertake imperfectly observable discretionary actions that affect the welfare of the principal. Agency problems arise not only in relationships governed by the common law of agency, but also in trust law, corporate law, and a host of other contexts.

Agency problems are pervasive because no one has the skills necessary to do everything for oneself and because every undertaking has an opportunity cost. By delegating a task to an agent, the principal benefits from specialist service and is freed to undertake some other activity. But these benefits come at the cost of being made vulnerable to abuse if the agent is given discretion the exercise of which cannot easily be monitored. In such circumstances, the agent may be tempted to favor the agent's interests when they diverge from those of the principal. The losses and other inefficiencies resulting from this misalignment of interests are called agency costs. ${ }^{4}$

In regulating an agency relationship, the primary objective is containment of agency costs. This is the function of fiduciary obligation. In consequence, agency problems are the defining hallmark of categorical fiduciary relationships, such as between trustee and beneficiary, director and corporation, and lawyer and client. Agency problems also are the common thread in cases involving ad hoc imposition by courts of fiduciary status. ${ }^{5}$

Curbing the agent's discretion is an inadequate answer to an agency problem. Rarely can the principal spell out in advance what the agent should do in all possible future circumstances. Anticipating all future contingencies is all but impossible, and it is almost always infeasible to give instructions for every anticipated contingency. In the jargon of economic analysis, agency problems are caused by incomplete contracting owing to transaction costs.

In the context of a financial adviser with discretionary trading authority over a client's account, the unpredictable nature of financial markets makes it impossible for the client to specify in advance with particularity how the adviser should manage the client's portfolio. Instead, the customary practice is to give the adviser general guidance in the form of an investment policy statement. Indeed, the very purpose of retaining an agent with expertise, such as a financial adviser, is undermined if the agent is not given leeway to apply that expertise on behalf of the principal to changing conditions in accordance with the principal's general instructions.

Judging the agent's performance on the basis of his results is inadequate if circumstances outside of the agent's control may affect the outcome. Suppose a real estate agent cannot locate a suitable buyer for a home at the homeowner's desired price. The homeowner can seldom ascertain whether the agent's failure reflects the agent's inadequate effort or instead stems from the homeowner's overpricing, a slumping market, or another external factor. Likewise for a financial adviser, external factors may cause an adverse outcome even if the adviser acted competently and loyally in the best interests of the client.

Incentive-based compensation has the potential to ameliorate the agency problem, but not to resolve it. A real estate agent tasked with selling a home is usually compensated by a percentage of the sale price, which brings the agent's interests into closer alignment with those of the homeowner. But no compensation arrangement short of selling the house to the agent will completely remove the possibility of divergent interests and, hence, the temptation for the agent to favor the agent's own interests in such circumstances. Moreover, solving the incentive problem by selling the house to the agent creates a risksharing problem. An agent cannot bear the risk of buying all of his clients' homes, and his clients would still be dependent on his faithfulness in pricing the home.

In the context of a financial advisory relationship, the client almost certainly will have a different risk tolerance than the adviser. The adviser should design a portfolio for the client that is reasonably suited to the risk and reward objectives of the client. High-powered incentive compensation might induce the agent to maximize expected return irrespective of the client's risk tolerance, thus maximizing the adviser's expected compensation but exposing the client to too much risk.

In summary, the governance challenge in an agency relationship is inducing the agent to act loyally and competently in the best interests of the principal in circumstances in which the agent has unobservable but necessarily discretionary powers. In modern law, the principal mechanism to this end is the fiduciary obligation.

\section{Part II: The Fiduciary Governance Strategy}

Deterrence, loyalty, and care. Under modern law's fiduciary governance strategy, an agent is given broad 
discretionary powers to act in the moment, but afterward the principal is invited to scrutinize whether the agent's action was indeed in the principal's best interests. Stripped of legalistic formalisms and moralizing rhetoric, ${ }^{6}$ the functional core of the fiduciary obligation is deterrence. The agent is induced to act in the best interests of the principal by the threat of after-the-fact liability for failure to have done so. The agent must act in the best interests of the principal on pain of damages and disgorgement remedies.

Understood in this way, the operation of fiduciary obligation becomes intuitive. The core fiduciary duties are loyalty and care. The duty of loyalty proscribes misappropriation and regulates conflicts of interest, requiring the fiduciary to act in the best interests of the principal. In the law of agency, the duty of loyalty presumptively prohibits self-dealing and conflicts of interest. ${ }^{7}$ The law also imposes procedural and substantive safeguards on consent by the principal, chiefly full and fair disclosure by the fiduciary. ${ }^{8}$ The purpose is prophylactic. The rule is meant to induce the agent to refrain from self-dealing and avoid conflicts of interest, or to disclose the material facts of the matter to the principal so that he can make an informed decision whether to give consent. ${ }^{9}$

The duty of care prescribes the fiduciary's standard of care by establishing a "reasonableness" or "prudence" standard, the meaning of which is informed by industry norms and practices. The standard of care is objective, measured by reference to a reasonable or prudent person in like circumstances. If the fiduciary has specialized skills relevant to the principal's retention of the fiduciary, then the applicable standard of care is that of a reasonable or prudent person in possession of those skills. ${ }^{10}$

Because agency problems arise from incomplete contracting, the core duties of loyalty and care are phrased as standards that allow the court to decide whether, in view of all the facts and circumstances, the fiduciary acted competently and in the best interests of the principal. In effect, the loyalty and care standards empower the court to complete the parties' contract as regards the facts and circumstances that actually unfold. Instead of trying in advance to reduce to writing provisions for every future contingency, the parties need only address expressly those contingencies that are important and likely enough to warrant the transaction costs of express provision. For any other contingency, fiduciary obligation fills the gap.

Interpretive authority and subsidiary rules. As standards that allow for consideration of the relevant facts and circumstances, the duties of loyalty and care minimize error costs. But as is typical of legal standards, this reduction in error costs comes at the price of increased uncertainty and increased decision costs. The highly contextual nature of a standard makes prediction difficult and requires a more intensive judicial role. Two related fiduciary law developments mitigate these difficulties.

First, the normal accretive process of the common law has produced a rich body of interpretive authority on fiduciary matters, not only across decades of case law, but also across generations of treatises, restatements, and statutory codifications. This mass of authority improves predictability by providing instructive guidance on how the duties of loyalty and care will be applied in various circumstances. It also addresses the extent to which the parties may override the fiduciary obligation by explicit agreement and the remedies available to the principal for the fiduciary's breach of duty.

Second, accumulated experience with recurring, common sets of facts and circumstances has led to the development of subsidiary rules regarding the application of the duties of loyalty or care to those circumstances. Within the law of agency, the duties of loyalty and care have been elaborated by a host of specific rules, such as rules governing competition with the principal, keeping confidences, disclosure, and recordkeeping. ${ }^{11}$

The subsidiary rules simplify application of the fiduciary obligation to cases that fall within their terms, thus reducing decision costs. One need not show that the duty of care requires accurate recordkeeping, for example, if one can invoke a subsidiary rule that imposes such a duty. Moreover, the subsidiary rules offer the reduced decision costs of simple rules without increasing error costs by providing a roadmap for avoidance behavior. If the fiduciary acts in a manner that is inimical to the principal's interests but that does not fall within one or another subsidiary rule, the principal may invoke the broad duties of loyalty and care. Operating in tandem, the primary duties of loyalty and care and the specific subsidiary rules provide the decision costs advantage of rules and the error costs advantage of standards.

Because the fiduciary obligation operates as an after-the-fact compliance review of the fiduciary's conduct, and because the agency problem varies across fiduciary contexts, the precise contours of the fiduciary obligation vary across the fiduciary fields. The fiduciary obligation in trust law, for example, is generally stricter than in corporate law. But those differences are contextual. The agency problem in a family trust in which the beneficiaries have no exit option, and that is managed by a corporate 
fiduciary that cannot easily be replaced, differs significantly from the agency problem in a large, publicly traded corporation from which a shareholder can separate easily by selling his shares in a highly liquid securities market (the "Wall Street rule"). The adaptability of the fiduciary obligation explains the success of the fiduciary governance strategy.

Default and mandatory rules. It follows from the function of the fiduciary obligation that particular fiduciary duties yield to a contrary agreement of the parties. The rule that the fiduciary must act in the principal's best interests-in effect, to do what the parties would have agreed if they had considered a given contingency-does not apply with respect to a particular contingency if the parties entered into an express agreement on what the fiduciary should do in that event. In general, fiduciary duties are default rules that apply unless the parties have agreed otherwise.

Even the fiduciary duty of loyalty is subject to modification by agreement of the parties. If the principal gives informed consent to certain selfdealing by the fiduciary, the rationale for the prophylactic rule against self-dealing falls away. In such circumstances, the fiduciary may engage in the authorized self-dealing, provided that the fiduciary acts in good faith and the transaction is fair and in the best interests of the principal. ${ }^{12}$

However, there are mandatory rules in fiduciary law that cannot be overridden by agreement. For example, the principal cannot authorize the fiduciary to act in bad faith. ${ }^{13}$ Even if the principal authorizes self-dealing, fiduciary law provides substantive and procedural safeguards. The fiduciary must act in good faith and deal fairly with and for the principal, and the fiduciary must apprise the principal of the material facts-those that would reasonably affect the principal's judgment-in securing the principal's informed consent. ${ }^{14}$

The mandatory rules of fiduciary law serve an internal protective and cautionary function that protects the principal, and an external categorization function that protects third parties who deal with the fiduciary. With respect to the protective and cautionary function, the mandatory core insulates fiduciary obligations that the law assumes would not be bargained away by a fully informed, sophisticated principal. True, in an individual case, a particular principal might be fully informed and have good reason to want to bargain away something from the mandatory core. But such circumstances are infrequent enough that a prophylactic (if paternalistic) mandatory rule may be justified nonetheless, at least in traditional fiduciary fields such as trust and agency, in which the principal is commonly not sophisticated or fully informed.

With respect to the external categorization function, the mandatory core addresses the need for clean lines of demarcation across types of property arrangements to minimize third-party information costs. On this view, the mandatory rules police the categorical line between a fiduciary relationship and other arrangements. A person may give property to another person and authorize the other person to act whimsically with it or to keep it for herself. But this mode of transfer is an absolute gift, and this mode of holding property is fee simple. ${ }^{15}$

\section{Part III: Applying Agency Fiduciary Law to a Financial Adviser}

Suppose that under state law a financial adviser, $A$, is an agent of a client, $C$, with respect to $C$ 's brokerage account over which $A$ has discretionary trading authority. In such a situation, $A$ is a fiduciary who owes duties of loyalty and care to $C$. However, agency fiduciary law "is not monolithic in its operation. In particular, an agent's fiduciary duties to the principal vary depending on the parties' agreement and the scope of the parties' relationship." ${ }^{16}$ What follows, therefore, are several representative applications of A's fiduciary duties to $C$.

Duty of loyalty. Within the common law of agency, the fiduciary duty of loyalty requires an agent "to act loyally for the principal's benefit in all matters connected with the agency relationship." ${ }^{17}$ The agent must "refrain from using the agent's position or the principal's property to benefit the agent or a third party." ${ }^{18}$ The duty of loyalty therefore prohibits A from misappropriating C's property, ${ }^{19}$ and it regulates conflicts of interest in which the interests of $A$ or a third party (such as another client) may be at odds with the interests of C. ${ }^{20} \mathrm{~A}$ is prohibited from undertaking any conflicted action for which $A$ does not first obtain $C$ 's informed consent. ${ }^{21}$

Principal trades. Suppose that $A$ acts as a principal in a securities transaction with $C$. Such a transaction, known as a principal trade, involves $A$ acting simultaneously as an agent for the client on one side of the transaction and as a principal on A's own account on the other. Principal trades thus involve self-dealing, a kind of conflict of interest that is presumptively prohibited by the duty of loyalty. ${ }^{22}$

The prohibition of undisclosed self-dealing applies regardless of the fairness of the transaction and whether the principal was harmed. ${ }^{23}$ "An agent has a duty not to deal with the principal as or on behalf of an adverse party in a transaction connected with the agency relationship." ${ }^{24}$ This rule pertains to any transaction for which the agent "has a substantial 
economic interest in the party with whom the principal deals." ${ }^{25}$ Thus, a transaction by $A$ on behalf of $C$ with an affiliate of $A$ is treated as if $A$ acted on his own account.

The rule against self-dealing, a default rule, is a prophylactic safeguard against the agent's temptation to stray from the principal's bests interests - a temptation that is acute in a case of self-dealing, because the fiduciary is acting simultaneously on his own account. The law of agency "disallows the pursuit of self-interest as a motivating force in actions the agent determines to take on the principal's behalf. ... Unless the principal consents, ... [the duty of loyalty] requires that an agent refrain from using the agent's position or the principal's property to benefit the agent." 26 In this way, the duty of loyalty protects "the principal from the vulnerability that any relationship of agency creates by exposing the principal's property or interests more generally to the risk of self-interested action by the agent." 27

But surely there are circumstances in which $C$ would be benefited by trading with $A$. Perhaps $A$ is an underwriter in a firm-commitment initial public offering such that $A$ will have an inventory of shares that might be a prudent investment for $C$. Or perhaps $C$ would benefit from investment in other securities commonly involved in principal trades, such as government, municipal, or corporate debt, preferred securities, or brokered certificates of deposit.

With adequate disclosure, $A$ may obtain $C$ 's informed consent to a principal trade that is fair and in the best interests of $C$, overriding the presumptive ban on self-dealing. Fiduciary law continues to provide substantive safeguards, because A must still act in good faith and deal fairly with and for $C$. The law also provides procedural safeguards, because in securing $C$ 's consent, A must apprise the principal of material facts, which means full and fair disclosure of facts that would reasonably affect the principal's judgment. ${ }^{28} \mathrm{~A}$ bears the burden of establishing that $C$ 's consent was properly obtained and the underlying transaction was fair. ${ }^{29}$

If $C$ consents with particularity to principal trades by $A$ as a category of authorized self-dealing transactions, $A$ will not be required to obtain C's consent prior to each separate trade. In an ongoing relationship, $C$ can give categorical consent to a particular type of self-dealing that is expected to recur. ${ }^{30}$ However, as regards each individual trade, $C$ may still require $A$ to demonstrate that it was fair and made in good faith.

Usurpation of opportunity. Suppose that $A$ learns of a potential investment or business opportunity for $C$. If the opportunity is potentially valuable, A may be tempted to take personal advantage of it or to give it to an affiliate or a third party with whom A seeks to curry favor. But this is not permitted if $A$ is a fiduciary. The duty of loyalty requires $A$ to offer the opportunity to $C$. A may not take personal advantage of the opportunity without C's informed consent, which must be obtained in good faith and in accordance with the substantive and procedural safeguards described above.

Taking advantage of the opportunity without $C$ 's informed consent, known in the law as usurpation of an opportunity, is a form of prohibited self-dealing. ${ }^{31}$ If $A$ learned of the opportunity by reason of A's position as $C$ 's financial adviser, usurpation of the opportunity is also a breach of A's duty to protect $C$ 's confidential information and not to use $C$ 's property or information for A's own purposes or those of a third party. ${ }^{32}$

Secret profits and other material

benefits. The duty of loyalty prohibits
A from obtaining secret profits or other material benefits "in connection with transactions conducted or other actions taken on behalf of the principal or otherwise through the agent's use of the agent's position." 33 Thus, if A switches C's money market sweep account to a new fund that compensates $A$ for facilitating the switch, $A$ breaches the duty of loyalty unless he first makes full and fair disclosure to $C$ and obtains $C$ 's consent. ${ }^{34}$ Likewise, A may not accept an undisclosed commission from XYZ Company in return for steering $C$ to invest in XYZ. ${ }^{35}$

The rationale for this rule, which is yet another prophylactic imposed by the duty of loyalty, is that the desire for the secret profit or benefit from a third party might dull A's incentive to act in the best interests of $C$. A may not keep any such benefit; instead, he must turn it over to $C,{ }^{36}$ unless $A$ had obtained $C$ 's informed consent in accordance with the substantive and procedural safeguards described above. The Restatement (Third) of Agency, published by the American Law Institute in 2006, explains:

Although the agent may believe that no harm will befall the principal, the agent is not in a position disinterestedly to assess whether harm may occur or whether the principal's interests would be better served if the agent did not pursue or acquire the benefit from the third party. Only the principal can assess the potential impact on the principal's interests of an agent's anticipated receipt of a material benefit to be furnished by a third party. ${ }^{37}$

A potentially important application of this rule relates to the common practice in the mutual fund industry in which a fund pays a shareholder's broker or other financial intermediary for providing nondistribution related services to the shareholder. 
Conceptually, this practice runs afoul the proscription just described against third-party compensation of an agent for dealing with the third party on behalf of the principal. To avoid liability in such circumstances, in accordance with the procedural and substantive safeguards described above, $A$ would have to show that:

1. A provided $C$ with full and fair disclosure of the nature and extent of his compensation from and relationship with the provider of the financial product;

2. having received this disclosure, $C$ consented to A's compensation from the provider of the financial product;

3. in obtaining $C$ 's consent, $A$ acted in good faith; and

4. in advising $C$ with respect to the prudence of purchasing the financial product and thereafter in executing the purchase, $A$ acted in good faith and in $C$ 's best interests without regard to A's personal interest in compensation from the provider of the financial product. ${ }^{38}$

As with principal trading, $C$ 's consent could be given in the context of a categorical waiver if it were sufficiently descriptive. ${ }^{39}$

Duty of care. In all facets of the agency relationship, the fiduciary duty of care requires an agent "to act with the care, competence, and diligence normally exercised by agents in similar circumstances. ... If an agent claims to possess special skills or knowledge, the agent has a duty to the principal to act with the care, competence, and diligence normally exercised by agents with such skills or knowledge." 40 The duty of care is thus objective and relational. Industry norms and practices inform and give context to the duty of care. A court will consider "the skill and knowledge normally possessed by" other financial advisers in like circumstances ${ }^{41}$ and any overriding terms in the contract between $A$ and $C .{ }^{42}$

Executing orders. Suppose that $C$ instructs $A$ to make a particular trade for $C$ 's account. A "must comply with all lawful instructions received from" $C$ and "take action only within the scope of" A's actual authority. ${ }^{43}$ Consequently, A must "make reasonable efforts" to execute the trade. ${ }^{44}$ In determining whether $A$ made reasonable efforts, a court would likely be influenced by prevailing industry norms, in this context the norm of best execution.

But what if $A$ believes that the instruction is ill advised? A's duties in such circumstances depend on the scope of the agency relationship, which thus far has been assumed to encompass discretionary trading authority and so reliance by $C$ on the expertise of $A$ in choosing investments. On this assumption, although $A$ is under a duty to follow the instruction, $A$ also might be under a duty to warn $C$, explaining A's concerns. An agent's duty to give the principal information relevant to the agency relationship is a routine application of the duty of care. "An agent owes the principal a duty to provide information to the principal that the agent knows or has reason to know the principal would wish to have." 45 Hence, if $C$ 's instruction to $A$ is imprudent and it is within A's professional competence to know this, A must so advise $C$.

Suppose instead that the account is nondiscretionary and that $C$ has not established a practice of reliance on A's expertise in choosing investments. Because an agent's fiduciary obligation tracks the scope of the agency, the duty of care is more limited in such a nondiscretionary relationship. The Restatement explains:

Ordinarily, the scope of an agent's duty to be diligent is limited by the scope of the services the agent undertakes to perform for the principal. The scope of an agent's duty may be expanded by contract or by the existence of a special relationship of trust and confidence between agent and principal. For example, a securities broker's duty of diligence to a client who directs trading in the client's own account (a "nondiscretionary" account) is limited to executing the client's orders to purchase and sell securities in the account and does not extend to advising the client or issuing risk warnings on an ongoing basis. In contrast, a securities broker's duty may include the provision of advice and warnings when the broker's relationship with the client is one in which the client's trust and confidence are invited by the broker and given by the client. ${ }^{46}$

In accord with this analysis, courts have refused to impose liability on nondiscretionary custodians and brokers for executing imprudent trades ordered by the principal. ${ }^{47}$ In such cases, the duty of care of the custodian or broker is limited to reasonable care in executing the order.

A word of caution, however, is in order about the nondiscretionary cases. If a client reposes "trust and confidence" in a broker, then as remarked upon in the Restatement provision excerpted above, the broker's duty of care might require "the provision of advice and warnings." Returning to the relationship between $C$ and $A$, if $C$ retains $A$ only for financial advice, and does not give A discretionary trading authority, $A$ is nonetheless under a duty to have a reasonable basis for any advice given to $C$ and to disclose facts relevant to $C$ 's consideration of the advice. ${ }^{48}$

Discretionary portfolio management. As has been shown, A owes 
a duty of care to $C$ in all facets of their relationship. In exercising discretionary trading authority over $C$ 's account, A must "act with the care, competence, and diligence normally exercised by agents in similar circumstances." ${ }^{29}$ In applying this standard, a court would be influenced by prevailing industry norms for fiduciary investment management. Perhaps the most important such norm is the prudent investor rule, first developed within trust fiduciary law, and since extended into other fields.

\section{'6The financial adviser may be an agent of the client under the common law of agency, making the adviser a fiduciary \\ as a matter of state common law."}

Today, the trust law of every state includes a version of the prudent investor rule stated in the Restatement (Third) of Trusts and the Uniform Prudent Investor Act. Rooted in the teachings of modern portfolio theory, the rule requires a trustee to invest trust assets in accordance with an overall portfolio strategy that is diversified and has risk and return objectives reasonably suited to the purpose of the trust. ${ }^{50}$ Federal law imposes similar rules on the trustees of employee pension funds. ${ }^{51}$ The Uniform Prudent Management of Institutional Funds Act, adopted in almost every state, applies the prudent investor rule to the management of charitable endowments. ${ }^{52}$

Readily available other sources examine the prudent investor rule in greater depth. ${ }^{53}$ This paper therefore focuses on the potentially problematic application in the financial advisory context if $C$ instructs $A$ not to diversify a portfolio of public securities (or some other equally imprudent instruction). As has been noted, $A$ is under a duty to comply with an instruction from $C$, but this duty is subject to A's further obligation to give advice and warnings to $C$ if $A$ believes $C$ 's instruction is ill advised.

Because the fiduciary relation is one of trust and confidence, and not arm's length, within the law of trusts a trustee must make full and fair disclosure to a beneficiary in the context of an authorization not to diversify. ${ }^{54}$ Notice the similarity to fiduciary practice within the law of agency with respect to an agent with discretionary trading authority or otherwise in whom the principal has reposed trust and confidence.

In the context of a revocable trust, however, in which the trustee functions much like a nondiscretionary agent, the trustee is under a duty to comply with the instructions of the creator of the trust (the settlor, in trust parlance). ${ }^{55}$ In parallel with fiduciary practice within the law of agency for a nondiscretionary agent, the trustee of a revocable trust is not liable for executing imprudent instructions from the settlor. ${ }^{56}$

\section{Conclusion}

In contrast to an arm's length relationship, in which each party is free to be self-serving, in a fiduciary relationship the law requires the fiduciary to be other-regarding because of the potential for abuse inherent to the agency structure of the relationship. What is meant by other-regarding is defined by default fiduciary duties of loyalty, care, and a host of implementing subsidiary rules. These duties are subject to refinement by agreement of the parties, so long as the fiduciary remains obligated to act in good faith and in the interests of the principal.
The flexibility of the fiduciary concept explains the proliferation of the fiduciary governance strategy in dealing with agency problems.

Regardless of whether a financial adviser qualifies as an "investment adviser" under the federal securities laws, and so is a fiduciary under federal law, the adviser may be an agent of the client under the common law of agency. In such situations, as a matter of state agency law, the adviser is a fiduciary who will be subject to liability for any breach of his fiduciary duties to the client.

This paper has considered how agency fiduciary law might be applied to a financial adviser with discretionary trading authority over a client's account. To that end, it (1) surveyed the underlying governance or regulatory issue, known in the literature as an agency problem, to which the fiduciary obligation is directed; (2) examined the legal context by considering how fiduciary obligation mitigates this problem; and (3) examined several potential applications of agency fiduciary law to financial advisers, including principal trades and the role of informed consent by the client, organizing the discussion under the great fiduciary rubrics of loyalty and care.

\section{Endnotes}

1. On whether an agency relationship exists, see Restatement (Third) of Agency $\$ 1.01 \mathrm{cmts.} \mathrm{c,} \mathrm{d}$ (2006).

2. Even if the adviser is not an agent of the client, fiduciary status might be imposed ad hoc, as in Burdett v. Miller, 957 F.2d 1375, 1381-82 (7th Cir. 1992) (Posner, J.), and Patsos v. First Albany Corp., 741 N.E.2d 841, 849-50 (Mass. 2001); see also Laby, Arthur B. 2010. "Fiduciary Obligations of Broker-Dealers and Investment Advisers," Villanova Law Review 55: 701, 723 (stating that "whether an account is discretionary ... is usually determinative" of whether the broker is a fiduciary under state law). 
3. See Sitkoff, Robert H. 2011. "The Economic Structure of Fiduciary Law." Boston University Law Review 91: 1039.

4. See Jensen, Michael C., and William H. Meckling. 1976. "Theory of the Firm: Managerial Behavior, Agency Costs and Ownership Structure." Journal of Financial Economics 3: 305-308.

5. See Burdett, 957 F.2d at 1381-82 (noting fiduciary status by "per se categories" and by "ad hoc" imposition); Restatement (Third) of Agency \$8.01 cmt. c (2006) (noting imposition of fiduciary obligation "on the basis that one party to the relationship has in fact reposed trust and confidence in the other and has done so consistently with the other's invitation").

6. The most famous such rhetoric is that of Justice Benjamin Cardozo, then a judge on the New York Court of Appeals:

Many forms of conduct permissible in a workaday world for those acting at arm's length, are forbidden to those bound by fiduciary ties. A trustee is held to something stricter than the morals of the market place. Not honesty alone, but the punctilio of an honor the most sensitive, is then the standard of behavior. As to this there has developed a tradition that is unbending and inveterate. Uncompromising rigidity has been the attitude of courts of equity when petitioned to undermine the rule of undivided loyalty by the "disintegrating erosion" of particular exceptions. Only thus has the level of conduct for fiduciaries been kept at a level higher than that trodden by the crowd. It will not consciously be lowered by any judgment of this court.

Meinhard v. Salmon, 164 N.E. 545, 546 (N.Y. 1928) (citations omitted).

7. See Restatement (Third) of Agency \$8.01 (2006).

8. See id. $\$ 8.06$ \& cmt. c.

9. See id. $\$ 8.06 \mathrm{cmt}$. b.

10. See id. $\$ 8.08$.

11. See id. \$\$8.04, 8.05, 8.11, 8.12.

12. See id. \$8.06; Restatement (Third) of Trusts $\$ 78$ cmts. c, d (2007).

13. See Restatement (Third) of Agency $\$ 8.06(1)(\mathrm{a})$ (i), (2)(a) (2006); Restatement (Third) of Trusts $\$ 78 \mathrm{cmt}$. c(2) (2007).

14. See Restatement (Third) of Agency \$8.06(1)(a)(ii) (2006); Restatement (Third) of Trusts §78(3) (2007).
15. See Restatement (Third) of Agency $\$ 8.06 \mathrm{cmt}$. b (2006) ("A relationship between two parties in which it is agreed that one party shall have the right to take action that affects the legal relations of the other party without regard for whether the action is for that party's benefit is not a relationship of agency."); see also McNeil v. McNeil, 798 A.2d 503, 509 (Del. 2002) ("A trust in which there is no legally binding obligation on a trustee is a trust in name only and more in the nature of an absolute estate or fee simple grant of property.").

16. Restatement (Third) of Agency $\$ 8.01 \mathrm{cmt}$. c (2006).

17. Id. $\$ 8.01$.

18. Id. cmt. b.

19. "An agent has a duty ... not to use property of the principal for the agent's own purposes or those of a third party." Id. §8.05(1).

20. See id. \$\$8.02-8.04.

21. See id. $\$ 8.06$

22. See id. \$\$8.01, 8.03; Geman v. SEC, 334 F.3d 1183, 1189 (10th Cir. 2003).

23. See Restatement (Third) of Agency $\$ 8.03 \mathrm{cmt}$. b (2006).

24. Id. \$8.03.

25. Id. cmt. c.

26. Id. $\$ 8.01 \mathrm{cmt}$. b.

27. Id.

28. See id. \$8.06(1)(a)(ii); Geman v. SEC, 334 F.3d 1183, 1189 (10th Cir. 2003).

29. See Restatement (Third) of Agency $\$ 8.06 \mathrm{cmts}$. b, c (2006).

30. See id. \$8.06(1)(b) \& cmt. b.

31. See id. $\$ 8.02 \mathrm{cmt}$. d.

32. See id. $\$ 8.05$

33. Id. $\$ 8.02$

34. See O'Malley v. Boris, 742 A.2d 845, 850-51 (Del. 1999) (upholding complaint in which client alleged that broker received an inadequately disclosed equity stake in a joint venture with the fund in return for switching clients to the fund; broker should have disclosed that it "used the transfer of its clients' money to buy its share of the venture").

35. See Restatement (Third) of Agency $\$ 8.02 \mathrm{cmt}$. b, illus. 3 (2006)

36. See id. cmt. e.

37. Id. cmt. b.

38. See id. $\$ 8.06$ \& cmts. b, c.
39. See id. cmt. b.

40. Id. \$8.08.

41. Id. cmt. c.

42. See id. \$8.07.

43. Id. \$8.09; see, e.g., Cecka v. Beckman \& Co., 104 Cal. Rptr. 374 (Ct. App. 1972).

44. Restatement (Third) of Agency $\$ 8.08 \mathrm{cmt}$. d (2006).

45. Id. $\$ 8.11 \mathrm{cmt}$. b. 46. Id. $\$ 8.08 \mathrm{cmt}$. d.

47. See, e.g., Pavlovich v. Nat'l City Bank, 435 F.3d 560, 567-68 (6th Cir. 2006) (holding that agent had only a "very narrow fiduciary duty not to make unauthorized distributions"); de Kwiatkowski v. Bear, Sterns \& Co., 306 F.3d 1293, 1302 (2d Cir. 2002) (holding that "a broker owes no [fiduciary] duty to give ongoing advice to the holder of a nondiscretionary account").

48. Compare Hanly v. SEC, 415 F.2d 589, 596-97

(2d Cir. 1969), and Keenan v. D.H. Blair \& Co., 838 F. Supp. 82, 89 (S.D.N.Y. 1993), with Shearson Hayden Stone, Inc. v. Leach, 583 F.2d 367, 371-72 (7th Cir. 1978).

49. Restatement (Third) of Agency $\$ 8.08$ (2006).

50. See Uniform Prudent Investor Act \$\$2(b), 3 (1994); Restatement (Third) of Trusts $\$ 90(a)$, (b) (2007).

51. See 29 C.F.R. $\$ 2550.404 a-1(b)(1)(i)$ (2012) (interpreting ERISA §404(a)(1)(B), 29 U.S.C. $\S 1104(\mathrm{a})(1)(\mathrm{B}))$.

52. See Uniform Prudent Management of Institutional Funds Act \$3(e) (2006).

53. See Schanzenbach, Max M., and Robert H. Sitkoff. 2007. "Did Reform of Prudent Trust Investment Laws Change Trust Portfolio Allocation?" Journal of Law \& Economics 50: 681. Langbein, John H. 1996. “The Uniform Prudent Investor Act and the Future of Trust Investing." Iowa Law Review 81: 641.

54. See In re Saxton, 712 N.Y.S.2d 225 (App. Div. 2000).

55. See Restatement (Third) of Trusts $\$ 74$ (2007).

56. See McGinley v. Bank of Am., 109 P.3d 1146 (Kan. 2005).

\section{Citation}

Sitkoff, Robert H. "The Fiduciary Obligations of Financial Advisers under the Law of Agency." Journal of Financial Planning 27 (2): 42-49. 